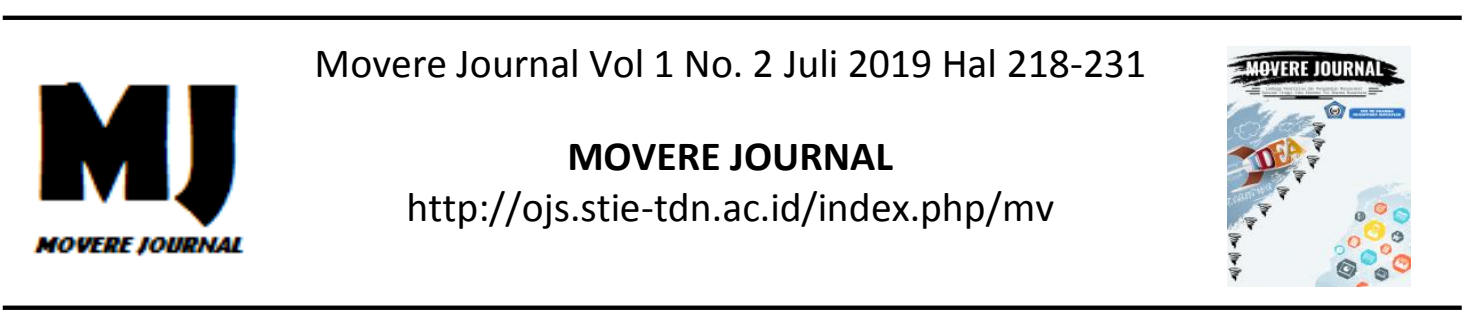

\title{
PENGARUH INOVASI DAN KUALITAS PRODUK TERHADAP KEPUASAN KONSUMEN PADA PRODUK BRIKET (CV. ARANG SURABAYA CAMPALAGIAN POLMAN)
}

\author{
Sumarsih \\ Universitas Sulawesi Barat
}

\begin{abstract}
Abstrak : Penelitian ini bertujuan untuk untuk mengetahui pengaruh inovasi dan untuk mengetahui pengaruh kualitas produk terhadap kepuasan konsumen di CV. Arang Surabaya Campalagian Polman. Metode penelitian yang digunakan adalah metode kuantitatif dan kualitatif. Hasil penelitian ini menunjukkan bahwa Constanta $=0.859$ menunjukkan nilai konstan, dimana jika nilai variabel independen sama dengan nol, maka kepuasan konsumen di CV. Arang Surabaya Campalagian Polman $(\mathrm{Y})=0.859$. Koefisien regresi inovasi $(\mathrm{X} 1)$ sebesar 0.192 artinya jika variabel independen lain nilainya tetap dan X1 mengalami kenaikan 1\%, maka kepuasan konsumen di CV. Arang Surabaya Campalagian Polman mengalami kenaikan sebesar 0.859 . Koefisien bernilai positif artinya terjadi hubungan positif antara inovasi dengan kepuasan konsumen di CV. Arang Surabaya Campalagian Polman, semakin meningkat inovasi maka kepuasan konsumen semakin meningkat. Koefisien regresi kualitas produk (X2) sebesar 0.742 ; artinya jika variabel independen lain nilainya tetap dan X2 mengalami kenaikan 1\%, maka kepuasan konsumen mengalami kenaikan sebesar 0.859. Koefisien bernilai positif artinya terjadi hubungan positif antara kualitas produk dan kepuasan konsumen, semakin meningkat kualitas produk maka kepuasan konsumen semakin meningkat.
\end{abstract}

Keyword : inovasi, kualitas produk dan kepuasan konsumen

\section{PENDAHULUAN}

Perkembangan dunia usaha dari tahun ke tahun mengalami berbagai peningkatan, persaingan akan semakin kompleks diera ekonomi asean (MEA), tingkat akselerasi yang tinggi dari setiap perusahaan menuntut perusahaan tersebut untuk memiliki kemampuan dalam mengembangkan pilihan strategi di bidang manajemen pemasaran sehingga mampu beradaptasi dengan lingkungan yang dinamis. Perubahaan lingkungan yang dinamis menuntut pasar harus dikelola dengan upaya-upaya yang sistematis untuk menempatkan keuntungan dari kinerja pasar yang superior (Nerver dan Slater, 1990).
Dengan meningkatnya usaha usaha yang ada semakin meningkat pula tingkat persaingannya. Usaha pemasaran briket arang yang bersumber dari pemanfaatan batok kelapa yang merupakan limbah dari tempurung kelapa yang dikeringkan kemudian dijadikan arang dan dijadikan briket selain memiliki nilai ekonomis yang tinggi juga memiliki banyak manfaat diantaranya dijadikan bahan bakar baik untuk kebutuhan rumah tangga maupun warung dan restoran . Tjiptono (2002:22) produk adalah segala sesuatu yang dapat ditawarkan oleh produsen untuk diperhatikan, diminta, dicari, dibeli, disewa, digunakan atau di konsumsi pasar (baik pasar konsumen akhir 
maupun pasar industri) sebagai pemenuhan kebutuhan atau keinginan pasar yang bersangkutan.

Inovasi yang dilakukan $\mathrm{CV}$. Arang Surabaya Campalagian Polman merupakan salah satu usaha penjualan briket arang yang berasal dari limbah batok kelapa yang diolah menjadi briket dengan tujuan selain meningkatkan kualitas produk juga memanfaatkan limbah menjadi barang yang mempunyai nilai jual yang tinggi sehingga menarik minat konsumen tidak hanya local akan tetapi sampai keluar daerah. Selain inovasi, Kualitas produk merupakan faktor penentu kepuasan konsumen setelah melakukan pembelian dan pemakaian terhadap suatu barang. Dengan kualitas produk yang baik maka keinginan dan kebutuhan konsumen terhadap suatu produk akan terpenuhi. Handoko (2002 : 23) kualitas produk adalah suatu kondisi dari sebuah barang berdasarkan pada penilaian atas kesesuaiannya dengan standar ukur yang telah ditetapkan. Semakin sesuai standar yang ditetapkan maka akan dinilai produk tersebut semakin berkualitas.

Tujuan perusahaan pada umumnya untuk memperoleh keuntungan, ini merupakan syarat untuk kelangsungan hidup perusahaan, dengan cara mempertahankan kualitas produk dan didukung inovasi yang terus dikembangkan oleh perusahaan. Kepuasan konsumen didefinisikan sebagai evaluasi pasca penggunaan bahwa suatu alternatif yang dipilih setidaknya memenuhi atau melebihi harapan konsumen (Tjiptono, 2004:125). Apabila sebuah perusahaan memberikan produk yang berkualitas baik, maka diharapkan mampu memenuhi harapan konsumen dan akhirnya mampu memberikan nilai yang maksimal serta menciptakan kepuasan pembelian yang positif bagi konsumen di banding kompetitorkompetitor yang ada.

CV. Arang Surabaya Campalagian Polman merupakan salah satu perusahaan yang terdapat di kota polewali mandar yang bergerak dalam bidang usaha pembuatan briket arang. Dalam hal ini perusahaan harus mengolah lebih dahulu bahan baku melalui proses produksi menjadi barang yang siap dijual. Untuk memperoleh hasil produksi yang baik dan memperoleh laba yang maksimal perusahaan ini harus terus berinovasi dan menjaga kualitas produk sehingga kepuasan konsumen bisa terpenuhi.

Berdasarkan latar belakang di atas maka rumusan masalah yang akan diteliti adalah bagaimana pengaruh inovasi dan kualitas produk terhadap kepuasan konsumen pada pada CV. Arang Surabaya Campalagian Polman, adapun tujuan penelitian ini adalah untuk mengetahui pengaruh inovasi dan kualitas produk terhadap kepuasan konsumen pada CV. Arang Surabaya Campalagian Polman.

\section{TELAAH LITERATUR DAN PENGEMBANGAN HIPOTESIS}

\section{Inovasi}

Inovasi adalah memulai atau memperkenalkan sesuatu yang baru. Inovasi memainkan peran penting dalam pencapaian tujuan organisasi, terutama dalam menciptakan produk-produk baru yang memenuhi kebutuhan pasar (Wong, 2012). Dengan inovasi yang dilakukan industry atau perusahaan, akan memberikan nilai tambah terhadap produk yang dimiliki sehingga harapan konsumen akan terpenuhi. Salah satu manfaat dari inovasi bertujuan mempercantik produk sehingga lebih menarik bagi para konsumen. Pengembangan produk melalui inovasi yang dilakukan oleh perusahaan dapat menciptakan keunggulan kompetitif selain itu akan menarik pelanggan baru, sementara pelanggan yang sudah ada akan tetap bertahan. Inovasi merupakan salah (C) 2019 STIE TDN. All rights reserved 
satu dampak dari perubahan teknologi yang cepat, baik itu inovasi proses maupun inovasi produk akan meningkatkan kemampuan perusahaan menciptakan produk yang berkualitas. Dengan produk yang berkualitas maka kepuasan konsumen akan terpenuhi. Inovasi merupakan proses teknologi, manajerial dan sosial, dimana gagasan atau konsep baru pertama kali diperkenalkan untuk dipraktekkan dalam suatu kultur (Quinn, Baruch \& Zien, 1996).

Dalam menghadapi persaingan, inovasi menjadi salah satu senjata yang ampuh untuk menciptakan kepuasan konsumen. Inovasi sebagai fenomena psikologi dan sosial budaya di mana kedua aspek tersebut dapat merupakan kunci keberhasilan atau kegagalan suatu organisasi (Daghfous, Petrof \& Pons, 1999). Tujuan utama proses inovasi adalah memberikan dan menyalurkan nilai pelanggan yang lebih baik. Pendekatan strukturalis memandang inovasi sebagai suatu unit dengan parameter yang tetap seperti teknologi dan praktek manajemen, adapun pendekatan proses memandang inovasi sebagai suatu proses yang kompleks, yang sering melibatkan berbagai kelompok sosial dalam organisasi (Swan, et al., 1999). Inovasi lebih merupakan aspek budaya organisasi yang mencerminkan tingkat keterbukaan terhadap gagasan baru. Inovasi produk didefinisikan sebagai produk atau jasa baru yang diperkenalkan ke pasar untuk memenuhi kebutuhan pasar (Damanpour, 1991).

\section{Kualitas Produk}

Kualitas merupakan konsep terpenting dalam menciptakan suatu produk. Produk yang berkualitas adalah produk yang diterima oleh konsumen sesuai dengan kebutuhan dan keinginan konsumen. Menurut Kotler (2012:54) produk adalah segala sesuatu yang dapat ditawarkan ke dalam pasar untuk diperhatikan, dimiliki, dipakai atau dikonsumsi sehingga dapat memuaskan keinginannya atau kebutuhannya. Oleh karena itu perusahaan harus mengerti apa yang menjadi kebutuhan dan keinginan konsumen.

Menurut Kotler dan Armstrong (2012:258): "Product quality stands the ability of a product to perform its function. It is includes the product's overall durability, reliability, precision, ease of operation and repair, and other value attributes. Some of these attributes can be measured objectively. From a marketing point of view, however, quality should be measured in term of buyer's perception."

Dapat diartikan bahwa kualitas suatu produk adalah kemampuan yang bisa dinilai dari suatu produk didalam menjalankan fungsinya, yang merupakan suatu gabungan dari daya tahan, keandalan, ketepatan, kemudahan pemeliharaan serta atributatribut lainnya dari suatu produk. Dari segi pemasar kualitas harus diukur dari sudut penglihatan dan tanggapan pembeli terhadap kualitas itu sendiri. Dalam hal ini selera pribadi sangat mempengaruhi. Oleh karena itu secara umum dalam mengelola kualitas produk, harus sesuai dengan kegunaan yang diharapkan.

Menurut Kotler (2012: 432) suatu produk dapat dievaluasi melalui 5 tingkatan produk, yaitu:

a. Core benefit, namely the fundamental service of benefit that the consumer is really buying, maksudnya bahwa core benefit (manfaat inti), yaitu manfaat utama yang diinginkan oleh seorang konsumen dalam membeli suatu produk.

b. Generic product, namely a basic version of the product, maksudnya bahwa generic product (produk dasar) yaitu gambaran fisik pada suatu produk

c. Expected product, namely a set of attributes and conditions that buyers 
normally expected and agree to purchase that product, maksudnya bahwa produk yang diharapkan, yaitu sejumlah atribut dan keadaan yang umumnya diharapkan dan disetujui oleh pembeli pada saat membeli produk tersebut.

d. Augmented product, namely one that includes additional service and benefits that company' $\mathrm{s}$ offer from competitor's offers, maksudnya bahwa manfaat tambahan produk, yaitu suatu produk yang dapat membedakan produk tersebut dengan produk pesaing.

e. Potential product, namely all of the augmentations and transformations that this product might ultimately undergo in the future, maksudnya bahwa potensi produk, yaitu perluasan perubahan yang mungkin dialami oleh suatu produk di masa yang akan datang.

\section{Kepuasan Konsumen}

Pengukuran kepuasan konsumen merupakan elemen penting dalam menyediakan pelayanan yang lebih baik, lebih efesien dan lebih efektif. Apabila konsumen merasa tidak puas terhadap suatu pelayanan yang disediakan, maka pelayanan tersebut dapat dipastikan tidak efektif dan tidak efesien.

\section{Jenis-Jenis Kepuasan Konsumen}

1). Kepuasan Konsumen dengan Keterlibantan yang Tinggi

Pembelian produk dengan keterlibatan yang tinggi secara psikologis penting bagi konsumen karena dapat memenuhi kebutuhan sosial atau pribadinya. Produkproduk ini terkait dengan kebutuhan pribadi dan sosial serta dapat menunjukkan citra diri konsumen itu sendiri. Akan tetapi, frekuensi pembelian produk tertentu, memungkinkan konsumen menilai merek mana yang terbaik dan selanjutnya membeli merek tersebut dengan sedikit pertimbangan di antara alternatif yang ada, sehingga dalam kepuasan pembelian dengan keterlibatan yang tinggi membuat konsumen terlibat dalam proses pengambilan kepuasan yang kompleks. Mereka mencari informasi secara luas dari berbagai sumber untuk mengevaluasi produk atau merek sebelum membeli.

2). Kepuasan Konsumen dengan Keterlibatan yang Rendah

Otoritas Pembelian produk dengan keterlibatan yang rendah tidak terlalu penting bagi konsumen, pencarian informasi untuk mengevaluasi merek-merek alternatif biasanya sedikit. Ketika suatu produk tidak terlalu penting dan mempunyai sedikit perbedaan yang mendasar antar merek, konsumen akan tetap membeli merek apa yang dia kenal.

Proses kepuasan konsumen menurut Philip Kotler (1988:170) terdiri dari lima tahap, yaitu pengenalan kebutuhan, pencarian informasi, evaluasi alternatif, kepuasan konsumen, paska pembelian. Kepuasan konsumen itu sendiri menurut Kotler (2002 : 204) adalah suatu tindakan konsumen untuk membentuk referensi diantara merek-merek dalam kelompok pilihan dan membeli produk yang paling disukai.

\section{Proses terjadinya Kepuasan}

Menurut Philip Kotler (2003204-208) konsumen melewati lima tahapan dalam proses kepuasan pembelian, sebenarnya proses pembelian telah dimulai jauh sebelum pembelian aktual terjadi dan memiliki konsekuensi jauh setelah pembelian terjadi. lima faktor internal yang relevan terhadap proses pembuatan kepuasan pembelian:

1) Motivasi (motivation) merupakan suatu dorongan yang ada dalam

(c) 2019 STIE TDN. All rights reserved 
diri manusia untuk mencapai tujuan tertentu.

2) Persepsi (perception) merupakan hasil pemaknaan seseorang terhadap stimulus atau kejadian yang diterimanya berdasarkan informasi dan pengalamannya terhadap rangsangan tersebut.

3) Pembentukan sikap (attitude formation) merupakan penilaian yang ada dalam diri seseorang yang mencerminkan sikap suka/tidak suka seseorang akan suatu hal.

4) Integrasi (integration) merupakan kesatuan antara sikap dan tindakan. Integrasi merupakan respon atas sikap yang diambil.

Perasaan suka akan mendorong seseorang untuk membeli dan perasaan tidak suka akan membulatkan tekad seseorang untuk tidak membeli produk tersebut.

\section{Briket Arang}

Briket arang adalah arang yang dibuat dari proses pembakaran dengan udara yang terkendali dan dibentuk sedemikian rupa yang dijadikan sebagai bahan bakar alternatif. Briket arang ini dibuat dari limbah diantaranya tempurung kelapa, serbuk kayu gergaji, tongkol jagung dan sebagainya yang dicampur dengan bahan perekat seperti perekat tepung tapioka, perekat tumbuh-tumbuhan dan sebagainya.

Briket arang merupakan bahan bakar alternatif yang terbuat dari hasil proses pembakaran bahan yang memiliki ukuran/diameter kecil (ranting, serbuk, serpih, sebetan, tempurung kelapa, tempurung kemiri dan lain-lain). Limbah dari pengarangan yang berupa bongkah arang yang berukuran kecil atau serbuk dapat diubah menjadi bentuk briket arang yang akan dapat memperbaiki sifat fisiknya terutama kerapatan, kebersihan dan ketahanan tekan serta memperlambat kecepatan pembakaran sehingga bentuk produk tersebut akan mempunyai ukuran yang sama dan lebih disenangi konsumen (Pari, dkk, 2012).

faktor-faktor yang perlu diperhatikan dalam pembuatan briket antara lain :

1. Bahan Baku

Bahan utama yang terdapat dalam bahan baku adalah selulosa. Semakin tinggi kandungan selulosa maka semakin baik kualitas briket.

2. Bahan Perekat

Bahan perekat dibedakan atas 3 jenis :

a. Perekat organik

Perekat organik yang termasuk jenis ini adalah sodium silika, magnesium, semen dan sulpit. Kerugian dari pengunaan perekat ini adalah sifatnya meninggalkan abu sekam pembakaran.

b. Bahan perekat tumbuh-tumbuhan Jumlah bahan perekat yang dibutuhkan untuk jenis ini jauh lebih sedikit bila dibandingkan dengan perekat hidrokarbon. Kerugian yang dapat ditimbulkan adalah arang cetak (briket) yang dihasilkan kurang tahan kelembaban.

c. Hidrokarbon dengan berat molekul besar

Bahan pertekat sejenis ini seringkali dipergunakan sebagai bahan perekat untuk pembuatan arang cetak batu bara cetak. Dengan pemakaian bahan perekat maka tekanan akan jauh lebih kecil bila dibandingkan dengan briket tanpa memakai perekat (Josep dan Hislop dalam Noldi, 2009 dalam Lukum, 2012).

Briket arang dihasilkan pada kondisi yang berbeda dan mempunyai karateristik berbeda pula. Karakteristik ini ditemukan pada bahan baku. Briket biomassa digunakan secara efisien dan secara rasional seperti bahan bakar. 
Hal ini ditandai dengan penentuan parameter seperti kelembaban, kadar abu, kepadatan, dekomposisi senyawa volatil, nilai kalor dan lain-lain (Oladeji, 2010).

Briket dengan kaulitas yang baik diantaranya memiliki tekstur yang halus, tidak mudah pecah, keras, aman bagi manusia dan lingkungan dan juga memiliki sifat-sifat penyalaan yang baik, diantaranya adalah: mudah menyala, waktu nyala cukup lama, tidak menimbulkan gelaga, asap sedikit cepat hilang dan nilai kalori yang cukup tinggi.

\section{METODE PENELITIAN}

Penelitian ini dilaksanakan pada industri pembuatan briket arang di CV. Arang SurabayaCampalagian Polman yang dilaksanakan 2 bulan yaitu bulan Maret-Mei 2019. Populasi penelitian ini adalah seluruh konsumen industri pembuatan briket arang di CV. Arang Surabaya Campalagian Polman. Sampel penelitian diambil dari 20 orang konsumen industri pembuatan briket arang CV. Arang Surabaya Campalagian Polman.

\section{Metode Pengumpulan Data}

\section{Penelitian Lapangan ( Field research )}

Penelitian lapangan yaitu penelitian dilakukan langsung kepada objek penelitian dengan tujuannya untuk dapat menggambarkan semua fakta yang terjadi pada objek penelitian sehingga permasalahan dapat diselesaikan yaitu data atau dokumen berupa profil usaha dan hasil angket yang dibagikan kepada responden Sugiyono (2007:122).

\section{Wawancara Interview (Interview)}

Menurut Sugiyono (2007:137)

Interview adalah salah satu pengumpulan data dengan jalan tanya jawab sepihak yang dikerjakan sistematis dan berdasarkan pada tujuan penelitian. Wawancara digunakan sebagai teknik pengumpulan data apabila peneliti ingin melakukan studi pendahuluan untuk menemukan permasalahan yang harus diteliti, dan juga apabila peneliti ingin mengetahui hal-hal dari responden yang lebih mendalam dan jumlah respondennya sedikit atau kecil.

\section{Metode Analisis Kuantitatif}

Metode yang akan digunakan dalam penelitian ini adalah Metode Analisis Regresi Berganda untuk menguji hipotesis dengan bantuan program SPSS 16 dengan rumus :

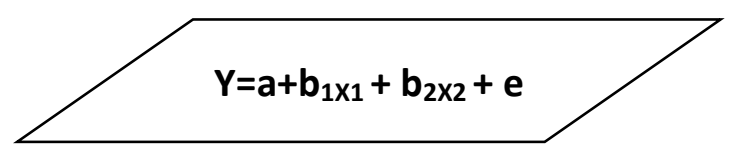

Dengan :

$$
\begin{array}{ll}
\mathrm{Y} & =\text { Kepuasan Konsumen } \\
\mathrm{X}_{1} & =\text { Inovasi } \\
\mathrm{X}_{2} & =\text { Kualitas Produk } \\
\mathrm{B}_{1}, \mathrm{~B}_{2} & =\text { Koefisien Regresi } \\
\mathrm{a} & =\text { Nilai Konstanta }
\end{array}
$$

Selanjutnya untuk mengetahui pengaruh variabel bebas terhadap variabel terkait baik secara bersamasama maupun secara sendiri digunakan uji-F, uji-t dan koefisien determinasi $\mathrm{R}_{2}$ dan parsial $\mathrm{r}_{2}$.

Untuk menguji hipotesis yang diajukan tersebut sebagai berikut (Sugiyono, 2010 :

1.Uji t ( Parsial ) digunakan untuk menguji parameter koefisien regresi setiap peubah bebas secara parsial. Jika suatu faktor $X$ mempunyai pengaruh terhadap $Y$, Jika nilai $t_{\text {hitung }}$ lebih besar $t$ tabel atau nilai probabilitas hitung lebih kecil dari a $(\mathrm{a}=5 \%)$ pengaruh disini berarti bahwa terjadi penolakan terhadap $\mathrm{H}_{0}$ sedangkan kebalikannya jika nilai $t_{\text {hitung }}$ lebih kecil $t_{\text {tabel }}$ atau nilai probabilitas hitung lebih besar dari a 
$(\mathrm{a}=5 \%)$ maka menunjukkan faktor $\mathrm{X}$ tidak mempunyai pengaruh terhadap Y.

$t_{\text {hitung }}>t_{\text {tabel }}$ atau $P$ value $<a$, Tolak $\mathrm{H}_{0}$

$\mathrm{t}_{\text {hitung }}<\mathrm{t}_{\text {tabel }}$ atau $\mathrm{P}$ value $<\mathrm{a}$, Terima $\mathrm{H}_{0}$

2.Uji F (Pengujian Serentak) digunakan untuk menguji kesesuaian model secara serentak apakah harga dan kualitas produk berpengaruh terhadap kepuasan pembelian konsumen. Jika dijabarkan lebih lanjut :

$\mathrm{F}_{\text {hitung }}<\mathrm{F}_{\text {tabel }}$ maka $\mathrm{H}_{0}$ diterima artinya faktor $\mathrm{X}$ secara bersama tidak berpengaruh nyata terhadap $\mathrm{Y}$.

$\mathrm{F}_{\text {hitung }}>\mathrm{F}_{\text {tabel }}$ maka $\mathrm{H}_{0}$ ditolak artinya minimal ada satu faktor $X$ yang berpengaruh nyata terhadap $\mathrm{Y}$.

3.Untuk melihat kedekatan hubungan antara variabel bebas (Independent Variabel) terhadap variabel terikat (Dependent Variabel) dijelaskan koefisien korelasi ( $\mathrm{R}$ ) apabila nilai $\mathrm{R}>0,5$ berarti hubungan kuat, $\mathrm{R}=$ 0,5 berarti hubungan sedang dan $\mathrm{R}<$ 0,5 berarti hubungan lemah.

Untuk mengestimasi persentase ketergantungan variabel terikat (Dependent Variabel) dan konstanta interskep dijelaskan oleh koefisien determinasi (pengaruh) $\mathrm{R}^{2}$ atau $\mathrm{R}$ square dan apabila interskep dikeluarkan maka $\mathrm{R}^{2}$ menjadi $\mathrm{R}^{2}$ terkorelasi. Nilai $\mathrm{R}^{2}$ menunjukkan koefisien determinasi yaitu seberapa besar perubahan variabel terikat diakibatkan oleh perubahan variabel.

\section{HASIL PENELITIAN DAN PEMBAHASAN}

\section{Analisis Statistik Deskriptif}

Dari hasil data yang telah dikumpulkan, maka diperoleh deskriptif data penelitian sebagai berikut :

Table 4.8 Descriptive Statistics

\begin{tabular}{|l|r|r|r|r|r|}
\hline \multicolumn{7}{|c|}{ Residuals Statistics $^{\mathbf{a}}$} \\
\hline & $\mathrm{N}$ & Minimum & Maximum & \multicolumn{1}{c|}{ Mean } & $\begin{array}{c}\text { Std. } \\
\text { Deviation }\end{array}$ \\
\hline Inovasi & 20 & 1 & 19 & 22.40 & 3.020 \\
\hline Kualitas Produk & 20 & 4 & 16 & 21.18 & 2.438 \\
\hline Kepuasan & 20 & 2 & 18 & 20.50 & 2.810 \\
Konsumen & & & & & \\
\hline Valid N (listwise) & 20 & & & & \\
\hline
\end{tabular}

Sumber : Data Primer Diolah SPSS, 2019

a. Dari tabel diatas dapat diketahui deskripsi data penelitian sebagai berikut : inovasi $\left(\mathrm{X}_{1}\right)$ dengan jumlah data $(\mathrm{N})$ sebanyak 20 mempunyai nilai minimum sebesar 1, Nilai maksimum sebesar 19, rata-rata sebesar 22.40 dan standar deviasi sebesar 3.020. Dengan melihat nilai ratarata yang berada pada range nilai minimum dan maksimum, maka variabel harga dapat dikatakan berdistribusi normal.

b. Dapat diketahui deskripsi data penelitian dari tabel diatas sebagai berikut : kualitas produk $\left(\mathrm{X}_{2}\right)$ dengan jumlah data $(\mathrm{N})$ sebanyak 20 mempunyai nilai minimum sebesar 4, Nilai maksimum sebesar 16, rata-rata sebesar 21.18 dan standar deviasi sebesar 2.438. Dengan melihat nilai rata-rata yang berada pada range nilai minimum dan maksimum, maka variabel kualitas produk dapat dikatakan berdistribusi normal. 
c. Kepuasan Konsumen (Y) dengan jumlah data $(\mathrm{N})$ sebanyak 20 mempunyai nilai minimum sebesar 2, Nilai maksimum sebesar 18, rata-rata sebesar 20.50 dan standar deviasi sebesar 2.810. Dengan melihat nilai ratarata yang berada pada range nilai minimum dan maksimum, maka variabel inovasi dapat dikatakan berdistribusi normal pada kepuasan konsumen dengan meningkatkan inovasi sehingga tercapai kepuasan konsumen.Analisis ini dilakukan untuk mendapatkan gambaran mengenai jawaban responden mengenai variabel-variabel penelitian yang digunakan.

Uji Validitas Instrumen Penelitian. Uji validitas
Uji validitas digunakan untuk mengukur valid tidaknya suatu kuesioner. Suatu kuesioner dikatakan valid atau sah jika pertanyaan pada kuesioner mampu mengungkapkan apa yang seharusnya diukur (Ghozali, 2013). Asumsi yang digunakan dalam uji validitas adalah jika $\mathrm{r}$ hitung lebih besar dari $\mathrm{r}$ tabel ( $\mathrm{r}$ hitung $>\mathrm{r}$ tabel) maka item dinyatakan valid. Karena skala pengukuran dari data ordinal maka uji validitas dalam penelitian ini menggunakan korelasi Pearson Product yang dapat dilihat pada tabel 4.9, tabel 4.10, dan tabel 4.11 dibawah. Pengujian validitas instrument dengan bantuan perangkat lunak SPSS. Nilai validitas dapat dilihat pada kolom Corrected ItemTotal Colleration. Secara rinci hasil uji validitas dan relibilitas disajikan pada tabel dihalaman berikutnya.

Table 4.9 Hasil Uji Validitas Variabel Inovasi ( $\left.X_{1}\right)$

\begin{tabular}{|c|c|c|c|c|}
\hline \multirow{2}{*}{ No } & \multirow{2}{*}{ Indikator } & $\mathbf{R}$ & $\mathbf{R}$ & \multirow{2}{*}{ Keterangan } \\
\cline { 3 - 4 } & & Tabel & Hitung & \\
\hline 1 & Pertanyaan 1 & 0.316 & 0.758 & Valid \\
\hline 2 & Pertanyaan 2 & 0.316 & 0.816 & Valid \\
\hline 3 & Pertanyaan 3 & 0.316 & 0.681 & Valid \\
\hline 4 & Pertanyaan 4 & 0.316 & 0.819 & Valid \\
\hline 5 & Pertanyaan 5 & 0.316 & 0.872 & Valid \\
\hline
\end{tabular}

Data Diolah : SPSS, 2019

Dari tabel 4.9 di atas, seluruh item pertanyaan dari variabel $\mathrm{X}_{1}$ inovasi dinyatakan valid karena seluruh nilai $\mathrm{r}_{\text {hitung }}$ lebih besar dari nilai $r_{\text {tabel. }} \cdot r_{\text {tabel }}$ dicari pada signifikansi 0,05 dengan uji 2 sisi dan jumlah data $(n)=40$, maka didapat $r_{\text {tabel }}$ sebesar 0.316. Dengan tingkat signifikan dan keyakinan $\alpha=0,05 \%$, dan $r_{\text {hitung }}$ sebesar 0.872 Sehingga dinyatakan valid.

Table 4.10 Hasil Uji Validitas Variabel Kualitas Produk ( $\mathrm{X}_{\mathbf{2}}$ )

\begin{tabular}{|c|c|c|c|c|}
\hline \multirow{2}{*}{ No } & \multirow{2}{*}{ Indikator } & $\mathbf{R}$ & $\mathbf{R}$ & \multirow{2}{*}{ Keterangan } \\
\cline { 3 - 4 } & & Tabel & Hitung & Valid \\
\hline 1 & Pertanyaan 1 & 0.316 & 0.723 & Valid \\
\hline 2 & Pertanyaan 2 & 0.316 & 0.730 & Valid \\
\hline 3 & Pertanyaan 3 & 0.316 & 0.720 & Valid \\
\hline 4 & Pertanyaan 4 & 0.316 & 0.748 & Valid \\
\hline 5 & Pertanyaan 5 & 0.316 & 0.768 & \multicolumn{2}{c}{} \\
\hline
\end{tabular}

Sumber : Data Diolah, 2019 
Tabel 4.10 di atas, menunjukkan bahwa variable $\mathrm{X}_{2}$ kualitas produk dinyatakan valid karena seluruh nilai $\mathrm{r}_{\text {-hitung }}$ lebih besar dari nilai $\mathrm{r}$-tabel. $\mathrm{r}$ tabel dicari pada signifikansi 0,05 dengan uji 2 sisi dan jumlah data (n) $=40$, maka didapat $\mathrm{r}_{\text {-tabel }}$ rata-rata sebesar 0.316 dan $\mathrm{r}_{\text {-hitung sebar }}$ 0.768 Sehingga semua item pertanyaan dinyatakan Valid.

Table 4.11 Hasil Uji Validitas Variabel Kepuasan Konsumen ( Y)

\begin{tabular}{|c|c|c|c|c|}
\hline \multirow{2}{*}{ No } & \multirow{2}{*}{ Indikator } & $\mathbf{R}$ & $\mathbf{R}$ & \multirow{2}{*}{ Keterangan } \\
\cline { 3 - 4 } & & Tabel & Hitung & \\
\hline 1 & Pertanyaan 1 & 0.316 & 0.704 & Valid \\
\hline 2 & Pertanyaan 2 & 0.316 & 0.834 & Valid \\
\hline 3 & Pertanyaan 3 & 0.316 & 0.730 & Valid \\
\hline 4 & Pertanyaan 4 & 0.316 & 0.665 & Valid \\
\hline 5 & Pertanyaan 5 & 0.316 & 0.796 & Valid \\
\hline
\end{tabular}

Sumber : Data Diolah, 2019

Berdasarka hasil uji validitas di atas menunjukkan bahwa nilai $r_{\text {hitung }}$ sebesar 0.796 setiap instrument variabel terikat dari kepuasan konsumen (Y) yang diukur lebih besar dari nilai $r_{\text {tabel }}=0.316,(n)=40$ dengan tingkat signifikan dan keyakinan sebesar $\alpha=0,05 \%$ sehingga dinyatakan valid.

\section{Uji Reliabilitas}

Uji reliabilitas adalah alat untuk mengukur suatu kuesioner yang merupakan indikator dari variabel atau konstruk (Ghozali 2012). Untuk mengukur reabilitas digunakan dilakukan dengan uji statistik Cronbach Alpha. Suatu variabel dikatan reliabel jika memberikan nilai Cronbach Alpha>0,60 atau $\mathrm{r}$ alpha $>0,60$ (Ghozali 2012). Adapun hasil pengujian reliabilitas terhadap seluruh variabel penelitian dapat dilihat pada tabel dibawah ini :

Tabel 4.12 Uji Reabilitas Variabel Penelitian

\begin{tabular}{|l|c|c|}
\hline \multicolumn{1}{|c|}{ Variabel } & Cronbach $^{\prime}{ }_{\text {Alpha }}$ & Keterangan \\
\hline Inovasi & 0,803 & Reliabel \\
\hline Kualitas Produk & 0,789 & Reliabel \\
\hline Kepuasan Konsumen & 0,791 & Reliabel \\
\hline
\end{tabular}

Sumber : Data Diolah, 2019

Berdasarkan tabel di atas, dapat disimpulkan bahwa seluruh item pertanyaan pada setiap variabel penelitian dinyatakan reliabel karena memiliki nilai alpha yang lebih besar 0,791 sehingga layak untuk dianalisis lebih lanjut.

\section{Analisis Regresi Berganda}

Adapun hasil pengolahan data dengan analisis regresi berganda dengan program spss 24 adalah sebagai berikut : 
Tabel 4.13 Regresi Linier Berganda Variabel Penelitian

Coefficients $^{\mathbf{a}}$

\begin{tabular}{|c|c|c|c|c|c|c|}
\hline \multirow{2}{*}{\multicolumn{2}{|c|}{ Model }} & \multicolumn{2}{|c|}{$\begin{array}{l}\text { Unstandardized } \\
\text { Coefficients }\end{array}$} & \multirow{2}{*}{$\begin{array}{c}\text { Standardized } \\
\text { Coefficients } \\
\text { Beta }\end{array}$} & \multirow[b]{2}{*}{$\mathrm{t}$} & \multirow[b]{2}{*}{ Sig. } \\
\hline & & $\mathrm{B}$ & Std. Error & & & \\
\hline \multirow[t]{3}{*}{1} & (Constant) & .859 & 2.317 & & .371 & .713 \\
\hline & Inovasi & .192 & .148 & .207 & 1.300 & .201 \\
\hline & Kualitas produk & .742 & .183 & .644 & 4.052 & .000 \\
\hline
\end{tabular}

Sumber : Output SPSS

Dependent Variable: $\mathrm{Y}$

$\mathrm{Y}=0.859+0.192 \mathrm{X}_{1}+0.742 \mathrm{X}_{2}+\mathrm{e}$

Interpretasi dari persamaan regresi

tersebut dapat dijelaskan sebagai berikut :

1) Constanta (a) $=0.859$ menunjukkan nilai konstan, dimana jika nilai variabel independen sama dengan nol, maka kepuasan konsumen di CV. Arang Surabaya Campalagian Polman $(\mathrm{Y})=0.859$.

2) Koefisien regresi inovasi $\left(X_{1}\right)$ sebesar 0.192 artinya jika variabel independen lain nilainya tetap dan $\mathrm{X}_{1}$ mengalami kenaikan $1 \%$, maka kepuasan konsumen di CV. Arang Surabaya Campalagian Polman mengalami kenaikan sebesar 0.859. Koefisien bernilai positif artinya terjadi hubungan positif antara harga dengan di CV. Arang Surabaya Campalagian Polman, semakin meningkat inovasi maka kepuasan konsumen semakin naik.
3) Koefisien regresi kualitas produk $\left(\mathrm{X}_{2}\right)$ sebesar 0.742 ; artinya jika variabel independen lain nilainya tetap dan $\mathrm{X}_{2}$ mengalami kenaikan $1 \%$, maka kepuasan konsumen mengalami kenaikan sebesar 0.859. Koefisien bernilai positif artinya terjadi hubungan positif antara kualitas produk dan kepuasan konsumen, semakin meningkat kualitas produk maka kepuasan konsumen semakin naik.

\section{Hasil pengujian hipotesis}

\section{Uji F}

Uji F dilakukan untuk menguji apakah inovasi dan kualitas produk secara simultan atau bersamasama mempunyai pengaruh yang signifikan terhadap kepuasan konsumen. Nilai F hitung diperoleh dengan menggunakan alat bantu program statistik seperti terlihat dalam tabel 4.14

Tabel 4.14

Uji F (Simultan)

ANOVA ${ }^{b}$

\begin{tabular}{|l|l|r|r|r|r|c|}
\hline \multicolumn{2}{|l|}{ Model } & $\begin{array}{c}\text { Sum of } \\
\text { Squares }\end{array}$ & Df & Mean Square & F & Sig. \\
\hline \multirow{3}{*}{1} & Regression & 206.855 & 2 & 103.427 & 37.835 & $.000^{\mathrm{b}}$ \\
\cline { 2 - 7 } & Residual & 101.145 & 37 & 2.734 & & \\
\cline { 2 - 7 } & Total & 308.000 & 39 & & & \\
\hline
\end{tabular}

Berdasarkan tabel 4.14, dilihat dari $F_{\text {hitung }}>F_{\text {tabel }}(37.835>14.41)$, dengan tingkat signifikan sebesar 0,00 yang lebih kecil dari 0,05.
Dengan demikian, dapat disimpulkan bahwa hipotesis 3 diterima, karena inovasi dan kualitas produk memiliki pengaruh positif signifikan terhadap 
kepuasan konsumen di CV. Arang Surabaya Campalagian Polman.

\section{Uji t}

Uji t dilakukan untuk menguji secara parsial apakah variabel inovasi dan kualitas produk secara parsial mempunyai pengaruh terhadap kepuasan konsumen di CV. Arang Surabaya Campalagian Polman. Nilai $t$ hitung diperoleh dengan menggunakan alat bantu program statistik seperti terlihat dalam tabel 4.15.

Tabel 4.15

Uji t (Parsial)

Coefficients $^{\mathbf{a}}$

\begin{tabular}{|c|c|c|c|c|c|c|}
\hline \multirow{2}{*}{\multicolumn{2}{|c|}{ Model }} & \multicolumn{2}{|c|}{$\begin{array}{l}\text { Unstandardized } \\
\text { Coefficients }\end{array}$} & \multirow{2}{*}{$\begin{array}{c}\text { Standardized } \\
\text { Coefficients } \\
\text { Beta }\end{array}$} & \multirow[b]{2}{*}{$\mathrm{T}$} & \multirow[b]{2}{*}{ Sig. } \\
\hline & & B & $\begin{array}{l}\text { Std. } \\
\text { Error }\end{array}$ & & & \\
\hline \multirow[t]{3}{*}{1} & (Constant) & .859 & 2.317 & & .371 & .713 \\
\hline & Inovasi & .192 & .148 & .207 & 1.300 & .003 \\
\hline & Kualitas produk & .742 & .183 & .644 & 4.052 & .000 \\
\hline
\end{tabular}

Sumber : Output SPSS

Dependent Variable: (Y)

Hipotesis 1 menyatakan bahwa inovasi $\left(\mathrm{X}_{1}\right)$ berpengaruh positif terhadap kepuasan konsumen (Y). Pengambilan keputusan untuk hipotesis ini berdasarkan probabilitas dengan tingkat signifikan 0,05. Hal ini diperoleh dari hasil analisis regresi yaitu uji t-hitung $\mathrm{X}_{1}=1.300$ dan $\mathrm{t}_{\text {-tabel }}$ 301. Tampak bahwa untuk variabel $\mathrm{X}_{1}, \mathrm{t}^{-}$hitung $=1.300>\mathrm{t}$-tabel $=0.273$ dengan signifikansi sebesar $0,03<$ 0,05 . Nilai t-hitung yang lebih besar dari $\mathrm{t}$-tabel $_{\text {dan }}$ nilai signifikansi lebih kecil dari 0,05 menunjukkan bahwa $\mathrm{H} 1$ diterima, yang artinya bahwa inovasi $\left(\mathrm{X}_{1}\right)$ berpengaruh terhadap kepuasan konsumen (Y).

Hipotesis 2 menyatakan bahwa kualitas produk $\left(\mathrm{X}_{2}\right)$ berpengaruh positif terhadap kepuasan konsumen di CV. Arang Surabaya Campalagian Polman. Pengambilan keputusan untuk hipotesis ini berdasarkan probabilitas dengan tingkat signifikan 0,05 . Hal ini diperoleh dari hasil analisis regresi yaitu uji t-hitung $\mathrm{X}_{2}=4.052$ dan $\mathrm{t}_{\text {-tabel }}$ 0.273. Tampak bahwa untuk variabel $\mathrm{X}_{2}, \mathrm{t}_{\text {-hitung }}=4.052>\mathrm{t}_{\text {-tabel }}=0.273$ dengan signifikansi sebesar $0,00<$ 0,05 . Nilai t-hitung yang lebih besar dari $\mathrm{t}_{\text {-tabel }}$ dan nilai signifikansi lebih kecil dari 0,05 menunjukkan $\mathrm{H} 2$ diterima, yang artinya bahwa kualitas produk berpengaruh terhadap kepuasan konsumen (Y).

\section{Uji Koefisien Determinasi}

Untuk menguji besarnya variabel bebas dalam mempengaruhi variabel terikat dapat diketahui melalui nilai koefisien determinasi yang ditunjukkan oleh nilai Adjusted $R$ Square (R2). Uji Koefisien $R$ Square digunakan untuk mengukur keeratan hubungan antara variabel dependen dengan variabel independen. Semakin besar nilai koefisien korelasi menunjukkan hubungan semakin erat dan sebaliknya. Berikut hasil yang diperoleh: 
Tabel 4.16

Koefisien Determinasi

Model Summary ${ }^{b}$

\begin{tabular}{|c|c|c|c|c|c|c|c|c|c|}
\hline \multirow[b]{2}{*}{$\begin{array}{l}\text { Mode } \\
1\end{array}$} & \multirow[b]{2}{*}{$\mathrm{R}$} & \multirow[b]{2}{*}{ R Square } & \multirow[b]{2}{*}{$\begin{array}{l}\text { Adjusted R } \\
\text { Square }\end{array}$} & \multirow[b]{2}{*}{$\begin{array}{l}\text { Std. Error of } \\
\text { the Estimate }\end{array}$} & \multicolumn{5}{|c|}{ Change Statistics } \\
\hline & & & & & $\begin{array}{l}\text { R Square } \\
\text { Change }\end{array}$ & F Change & df1 & $\mathrm{df} 2$ & $\begin{array}{c}\text { Sig. F } \\
\text { Change }\end{array}$ \\
\hline 1 & $.820^{\mathrm{a}}$ & .672 & .654 & 1.653 & .672 & 37.835 & 2 & 37 & .000 \\
\hline
\end{tabular}

Berdasarkan tabel 4.16, Hasil analisis regresi secara keseluruhan menunjukkan $R$ Square sebesar $\quad 0,672$ yang berarti bahwa variabel inovasi dan kualitas produk dapat menjelaskan variabel kepuasan konsumen di CV. Arang Surabaya Campalagian Polman. Sebesar $58 \%$ dan selebihnya sebesar $42 \%$ dipengaruhi oleh variabel lain, berarti besaran pengaruh inovasi dan kualitas produk relative cukup besar pengaruhnya terhadap kepuasan konsumen di CV. Arang Surabaya Campalagian Polman.

\section{Pembahasan}

Penelitian ini merupakan studi yang melakukan analisis tentang hubungan inovasi, kualitas produk terhadap kepuasan konsumen. Hasil penelitian menunjukkan bahwa secara parsial inovasi dan kualitas produk berpengaruh positif signifikan terhadap kepuasan konsumen di CV. Arang Surabaya Campalagian Polman . Berdasarkan tabel 4.12, dilihat dari $\mathrm{F}$ hitung $>\mathrm{F}$ tabel $(37.835>14.41)$, dengan tingkat signifikan sebesar 0,00 yang lebih kecil dari 0,05. Dengan demikian, dapat disimpulkan bahwa hipotesis 3 diterima, karena inovasi dan kualitas produk memiliki pengaruh positif signifikan terhadap kepuasan konsumen di CV. Arang Surabaya Campalagian Polman.

Hasil pengujian hipotesis pertama menunjukkan bahwa variabel inovasi mempunyai tingkat signifikansi $0,03<0,05$, maka $\mathrm{H}_{1}$ diterima. Hal ini diperoleh dari hasil analisis regresi yaitu uji t-hitung $\mathrm{X}_{1}=1.300$ dan $\mathrm{t}_{\text {-tabel }}$ 301. Tampak bahwa untuk variabel $X_{1}$, $\mathrm{t}_{\text {-hitung }}=1.300>\mathrm{t}$-tabel $=0.273$ dengan signifikansi sebesar $0,03<$ 0,05 . Nilai t-hitung yang lebih besar dari $\mathrm{t}^{\mathrm{t}}$ tabel dan nilai signifikansi lebih kecil dari 0,05 menunjukkan bahwa $\mathrm{H} 1$ diterima, yang artinya bahwa inovasi $\left(\mathrm{X}_{1}\right)$ berpengaruh terhadap kepuasan konsumen (Y).

Hasil pengujian hipotesis kedua menunjukkan bahwa variabel kualitas produk mempunyai tingkat signifikansi $0,00<0,05$, maka $\mathrm{H}_{2}$ diterima. Hal ini diperoleh dari hasil analisis regresi yaitu uji t-hitung $\mathrm{X}_{2}=$ 4.052 dan $\mathrm{t}_{\text {-tabel }}$ 0.273. Tampak bahwa untuk variabel $\mathrm{X}_{2}, \mathrm{t}$-hitung $=4.052>\mathrm{t}$ tabel $=0.273$ dengan signifikansi sebesar $0,00<0,05$. Nilai t-hitung yang lebih besar dari $t_{\text {-tabel }}$ dan nilai signifikansi lebih kecil dari 0,05 menunjukkan bahwa Maka H2 diterima, yang artinya bahwa kualitas produk berpengaruh terhadap kepuasan konsumen (Y).

\section{KESIMPULAN}

\section{Kesimpulan}

Berdasarkan dari hasil penelitian dan pembahasan pada penelitian ini, maka dapat penulis simpulkan bahwa :
1) Constanta (a) $=0.859$ menunjukkan nilai konstan, dimana jika nilai variabel independen sama dengan nol, maka kepuasan konsumen di CV. Arang Surabaya Campalagian Polman $(\mathrm{Y})=0.859$.

2) Koefisien regresi inovasi $\left(X_{1}\right)$ sebesar 0.192 artinya jika variabel independen lain nilainya 
tetap dan $\mathrm{X}_{1}$ mengalami kenaikan $1 \%$, maka kepuasan konsumen di CV. Arang Surabaya Campalagian Polman mengalami kenaikan sebesar 0.859. Koefisien bernilai positif artinya terjadi hubungan positif antara inovasi dengan di CV. Arang Surabaya Campalagian Polman, semakin meningkat inovasi maka kepuasan konsumen semakin naik.

3) Koefisien regresi kualitas produk $\left(\mathrm{X}_{2}\right)$ sebesar 0.742 ; artinya jika variabel independen lain nilainya tetap dan $\mathrm{X}_{2}$ mengalami kenaikan 1\%, maka kepuasan konsumen mengalami kenaikan sebesar 0.859. Koefisien bernilai positif artinya terjadi hubungan positif antara kualitas produk dan kepuasan konsumen, semakin meningkat kualitas produk maka kepuasan konsumen semakin naik.

\section{Saran}

Dari hasil penelitian sebaiknya perusahaan terus berinovasi selain itu kualitas produk juga harus dijaga dalam pembuataan briket arang, apabila konsumen tertarik untuk membeli kembali maka kepuasan konsumen dapat terpenuhi.

\section{DAFTAR PUSTAKA}

Daghfous, N., Petrof, J. \& Pons, F. 1999. Value and Adoption of Innovations: A Cross-Cultural Study. The Journal Consumer Marketing, 16(4): 314-331

Damanpour, F. 1991. Organizational Innovation: A Meta Analysis of Effect of Determinants and Moderators. Academy of Management Journal, 34(3): 555-590

Ghozali, Imam,2012, Partial Least Square, Konsep, Metode dan Aplikasi Menggunakan Program
WarpPLS2.0,Badan Penerbit UNDIP

Ghozali, Imam, 2013. Aplikasi Analisis Multivariat dengan Program IBM SPSS 21. Edisi 7, Penerbit Universitas Diponegoro, Semarang

Handoko. (2002). Analisis Kualitas Produk dan Kualitas Layanan Terhadap Kepuasan Konsumen Pada Holland Bakery Boulevard Manado. Jurnal EMBA, Vol. 3 No. 1, september 2018, Hal. 1291-1302, ISSN: 2303-1174.

Narver, J., Slater, S., 1990, The Effect of a Market Orientation on Business Profitability, Journal of Marketing, vol 54

Kotler, P. (1988). Manajemen Pemasaran: Analisis, Perencanaan, Implementasi, dan Pengendalian Jilid 2. (Terjemahan Jaka Wasana). Jakarta: Erlangga. (Edisi asli diterbitkan tahun 1988 oleh Prentice Hall Inc.).

Kotler, Philip, 2002, "Manajemen Pemasaran Edisi Milenium" PT. Prehalindo, Jakarta

Kotler, Philip, 2003, "Marketing Management,"11th edition/ International Edition.Prentice Hall. New Jersey

Kotler, P., \& G. Amstrong. (2012). Prinsip-prinsip Pemasaran Jilid 1. (Terjemahan Bob Sabran). Edisi Keduabelas. Jakarta: Erlangga. (Edisi asli diterbitkan tahun 2008 oleh Pearson Education Inc. Pearson Prentice Hall).

Narver, J., Slater, S., 1990, The Effect of a Market Orientation on Business Profitability, Journal of Marketing, vol 54

Pari. (2012). Manfaat Briket Arang Bagi Kehidupan. Artikel Ilmiah. Bandung

Quinn, J.B., Baruch, J. \& Zien, K. A. 1996. Softwarebased innovation. 
Sloan Management Review, 37(4): 11-24

Sugiyono. (2007). Metode Penelitian Kuantitatif Kualitatif Dan R\&D.

Bandung: Alfabeta

Swan, J., Newel, H. Scarbrought \& Hislop.1999. Knowledge Management and Innovations: Networks and Networking. Journal of Knowledge Management, 3(4): 262-275

Tjiptono, F. (2002). Prinsip-prinsip Total Quality Service (TQS). Yogyakarta: Andi.

Tjiptono. F dan Chandra. G. 2004, "Service Quality \& Satisfaction" Penerbit Andi Yogjakarta 